\title{
LEEM MET STRO EN LOOD MET MELKGOUD FRAGMENT VAN EEN MUURSCHILDERING
}

Aan het begin van de $20^{e}$ eeuw vond een deel van een muurschildering van Chinese origine zijn weg naar de collectie van de Vereniging van Vrienden der Aziatische Kunst.

De oorspronkelijke plaats van herkomst weten we niet en de complete voorstelling waar het ooit deel van uitmaakte is ook nog steeds onbekend. We kunnen de weg die het fragment aflegde in omgekeerde volgorde traceren tot Parijs in de jaren twintig, maar eigenlijk blijft alles wat het daarvoor heeft meegemaakt een mysterie. Door te kijken naar de samenstelling van de materialen waaruit het fragment is opgebouwd zal ik in dit artikel proberen inzicht te geven in de manier waarop het vervaardigd is.

\section{Fysieke kenmerken}

Het is zonder meer duidelijk dat het nooit de bedoeling is geweest dat de schildering verplaatst zou worden. Hij is gemaakt als vastzittende schildering op een muur van een gebouw waarvan we de functie slechts kunnen raden. Het is op zichzelf geen complete, iconografisch herkenbare voorstelling en er valt dan ook uit dit relatief kleine fragment niet af te leiden of het voor een tempel, een graftombe of misschien zelfs ter verfraaiing van een woning werd gemaakt.

Het fragment is al jaren in een houten kist ingelijst met aan de voorzijde glas zodat van de voorstelling zoveel mogelijk te zien is. Voor mijn onderzoek naar de materialen moest deze kist geopend worden. Het openmaken en vervolgens uit de kist halen van het fragment gebeurde onder de deskundige leiding van Isabelle Garachon, hoofdconservator voor keramiek en glas van het Rijksmuseum. Het was een spannende aangelegenheid, waarbij van te voren niet met zekerheid te zeggen was of het fragment in de loop der jaren zijn stevigheid en samenhang zou hebben behouden. Gelukkig bleek het fragment opgebouwd uit een goed bewaard gebleven constructie van verschillende lagen, waarover later meer. Na opening van de kist was het fragment voor het eerst in vele jaren in zijn volle glorie te zien. Deze gelegenheid is natuurlijk aangegrepen om een nieuwe serie foto's te laten maken.

\section{Een klein stukje geschiedenis}

Enige informatie over de herkomst van het fragment is te vinden in een getypt document: 'Geschiedenis der Vereniging van Vrienden der Aziatische Kunst te boek gesteld vanaf 5 oktober 1955' door H.F.E. Visser. Visser was een van de oprichters van de vereniging in 1918 en hij schreef dit niet 'uit ijdelheid', zoals hij het zelf formuleert, maar om het tot stand komen van de VVAK duidelijker en begrijpelijker te maken. Visser noemt in zijn verhaal het 
In het speciale nummer van het bulletin van de Vereniging, getiteld 'Legaat Westendorp', staat een introductie door Maartje Draak. ${ }^{1}$ Hier vinden we meer informatie die direct betrekking heeft op dit object. De beschrijving is als volgt:

'China, vermoedelijk $14^{\mathrm{e}}$ eeuw. $43 \times 55 \mathrm{~cm}$. Bestaat uit leem vermengd met stro, waarop aangebracht kleuren en vergulde pâte. Boeddhistische voorstelling. De voorste van de knielende figuren biedt op een blad een cintâmani (Magisch Juweel, dat alle wensen vervult) bekroonde doos aan. De beide andere figuren dragen een kuei (jade tablet, gebruikt als onderscheidingsteken van rang). De herkomst: Blondeau, Parijs, 1924.' Hierop volgen nog enkele literatuurverwijzingen.

Van de omzwervingen van het fragment voor het in 1924 in Parijs opdook is, zoals eerder gezegd, weinig of niets bekend. Bij het Parijse veilinghuis Blondeau maakte het onderdeel uit van een veiling met meerdere vergelijkbare fragmenten en op de inventariskaart staat de vermelding dat de fragmenten waarschijnlijk via 'Loo of Wannieck' in Parijs beland zijn. In een briefwisseling van juli 1924 tussen de heer H.F.E. Visser en Monsieur L. Wannieck in Parijs is sprake van een fresco dat voor 2000 francs aangekocht is. Dit zou ons fragment kunnen zijn, maar er is tevens sprake van een ander fragment: '(...) le fragment de fresque a quatre personnages de frs. 3800.- (...).' De beschrijving geeft aan dat er vier figuren op deze muurschildering staan, terwijl er slechts drie figuren op onze schildering staan. Bij het onderzoek blijkt echter dat een vierde figuur aan de linkerrand overschilderd is, en er valt dus niet uit te sluiten dat dit toch ons fragment betreft.

Het zou hier ook kunnen gaan om een ander fragment dat nu deel uitmaakt van de collectie. Dat fragment is, volgens de beschrijving op de inventariskaart van de VVAK in 1946, door Visser voor 1000 gulden aangekocht bij Blondeau en maakt nu ook deel uit van de collectie met als nummer MAK 90. In een catalogus uit 1926 van de eerder genoemde kunsthandelaar uit Parijs,

Afbeelding 2 Achterkant van het fragment.

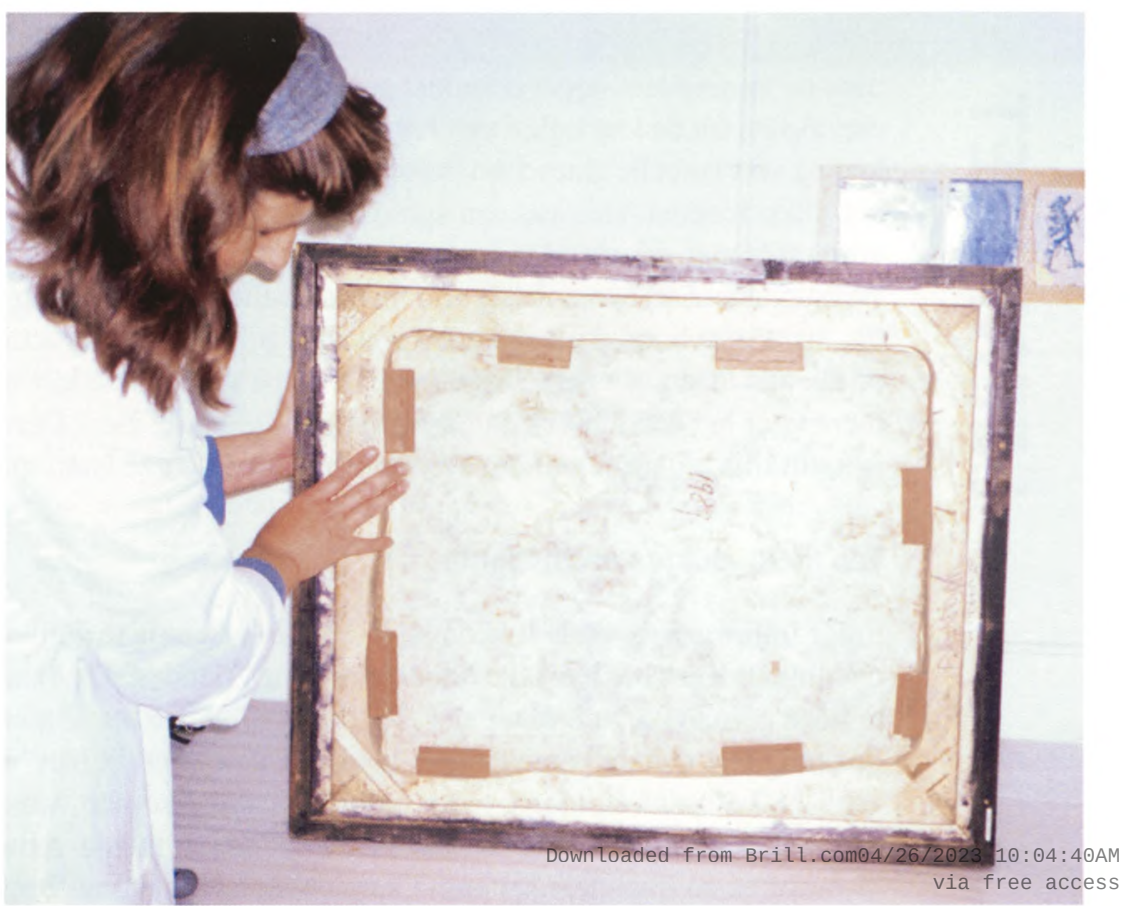


Paul Blondeau, staan afbeeldingen van een aantal vergelijkbare fragmenten mogelijk afkomstig van dezelfde muur of een andere muur in hetzelfde gebouw. Hoewel de voorstelling van MAK 90 weliswaar in stijl lijkt op een van de in de catalogus afgebeelde fragmenten, moeten we vaststellen dat het hier toch om een ander fragment gaat. De maat $33 \times 35 \mathrm{~cm}$ komt ook niet overeen met de maat die Blondeau vermeldt: $55 \times 43 \mathrm{~cm}$. Waar de overige fragmenten zich bevinden, is op dit moment niet bekend, waarschijnlijk zijn ze opgenomen in een particuliere verzameling.

In 1924 werden de eerste stappen gezet om tot de organisatie van een tentoonstelling van Chinese kunst te komen in het Stedelijk Museum te Amsterdam. In 1925 vond de eerste serieuze en belangrijke tentoonstelling van Chinese kunst plaats en de muurschildering MAK 529 maakte deel uit van die expositie.

De Engelstalige catalogus vermeldt naast de eerder gegeven informatie ook nog: 'De tempelmuur is gedecoreerd met onder andere een draak en een feniks. ${ }^{2}$ Sommige opgehoogde delen zijn verguld [p. 34, vertaling LvV].' Hier wordt als datering gegeven de Yuan- (1279-1368) of vroege Ming-periode (1368-1644), vervolgens wordt 'een noordelijke academische stijl' genoemd en als herkomst waarschijnlijk Noord-Henan.

De eerste kleurenfoto's van het fragment zijn in 1926 gemaakt voor de speciale catalogus van de 'Tentoonstelling van Chineesche Kunst'. Voor het fotograferen werd een, destijds nogal spectaculaire, nieuwe techniek gebruikt: het Frisch-procédé. Daarvoor was het echter nodig het hele fragment naar de studio van de fotograaf Frisch in Berlijn te vervoeren. Als rechtmatige eigenaar gingen de heer Westendorp vergezeld door zijn vrouw en de eerder genoemde heer Visser mee als begeleiders van het kostbare fragment. Voor alle zekerheid reisde de schildering in een eigen couchette in de trein zodat de veiligheid gegarandeerd was.

\section{Visuele inspectie}

Terug nu naar het fragment dat onderzocht zou worden. De voorstelling is geschilderd op een ondergrond die op het eerste gezicht bestaat uit een laag geelgrijze leem van zo'n $10 \mathrm{~cm}$ dik. ${ }^{3}$ Het is vreemd te bedenken dat dit alles is wat resteert van de oorspronkelijke muur waarop het ooit geschilderd werd. Wanneer de kist opengaat wordt het door de losse en eruit vallende strootjes direct duidelijk dat in de grondlaag stro is verwerkt als versterkingsmateriaal; stro bevordert de samenhang in de ondergrond. De achterzijde van het fragment blijkt beplakt te zijn met - vermoedelijk zijdehoudend - chinees papier met in zwarte inkt het opschrift '1989'. Het is niet bekend of dit werkelijk in 1989 is aangebracht en ik heb ook niet kunnen achterhalen wie dit gedaan heeft. Het papier is ongetwijfeld aangebracht ter bescherming en daarom is het niet verstandig een monster uit de diepere lagen van de achterkant te nemen. Ik zag daar met enige spijt van af; een onverstoord monster van het stro in de kern zou mogelijk een indicatie van de periode waarin het gemaakt is kunnen opleveren via de C14-dateringsmethode. Hopelijk zal het in de toekomst mogelijk worden via een non-destructieve methode dit soort gegevens te achterhalen.

Bij de volgende stap werd het fragment omgekeerd en dan is de schildering aan de voorzijde te zien zonder invloed van het glas van de lijst. Wat mij direct opviel is de ogenschijnlijk zonder zichtbare penseelstreken aange- 10 :04:40AM brachte groene laag met hier en daar kleine ronde putjes in de verflaag. ${ }^{\text {free }}$ access 

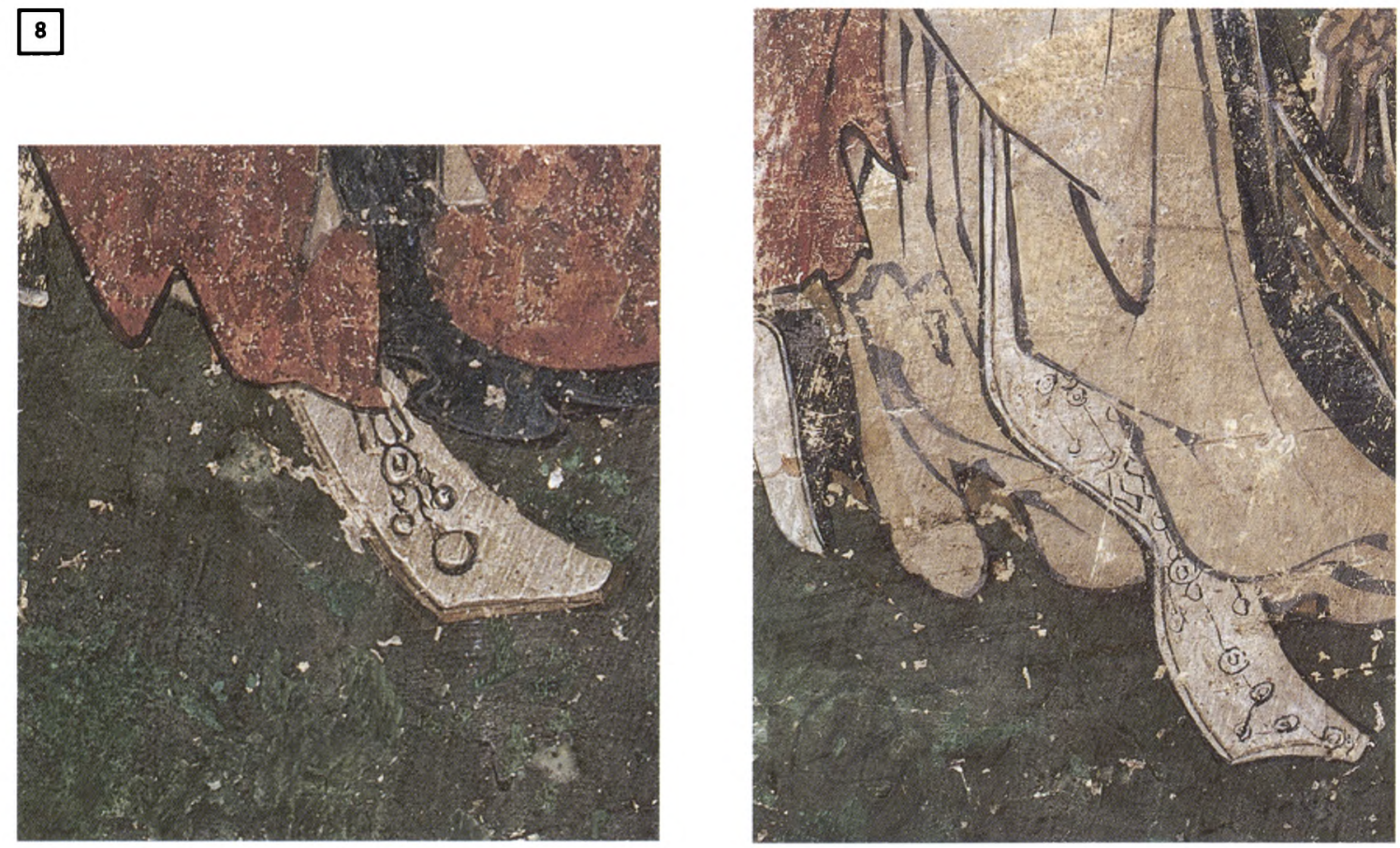

Afbeelding 3 (links) Detailopname van de groene vloer.

Afbeelding 4 De Chinese lijnen zijn hier krachtig en scherp, de restauratie is met bibberende lijnen aangebracht.
Dergelijke kleine putjes doen zich voor wanneer er met een grote slappe kwast een gelijkmatige laag aangebracht wordt van een met water verschilderbare verf: tijdens het drogen van de verflaag ontstaan er dan ronde kratertjes waar het water een belletje gevormd heeft zonder dat zich op die plek pigmentkorrels hebben kunnen afzetten. Het monster dat wij namen van de hier genoemde groene verf is helaas verloren gegaan bij het inbedden, het laten verzinken van het buitengewoon kleine monster in transparant polyester waardoor het hanteerbaar wordt. Hoewel hieruit geen harde conclusie getrokken mag worden, zou het mogelijk een gevolg van de wateroplosbaarheid van de verf kunnen zijn.

\section{Restauraties}

Eerdere restauraties van het fragment zijn duidelijk herkenbaar, bijvoorbeeld aan de kleine streepjes verf die gebruikt zijn ter invulling van plaatsen waar de originele verflaag beschadigd is. Vooral op wat grotere kleurvlakken is deze restauratiemethode sinds enkele tientallen jaren heel gebruikelijk. Het grote voordeel is dat men van de normale kijkafstand een compleet beeld van de voorstelling kan zien, terwijl van dichtbij bekeken de streepjes duidelijk aangeven dat het ingeschilderde niet tot de originele verflaag behoort.

Op enkele andere plaatsen zijn echter restauraties aanwezig die middels een andere methode werden ingeschilderd, hetgeen duidt op een veel vroeger tijdstip. Deze reparaties stammen waarschijnlijk van voor de aankoop in de jaren twintig van de vorige eeuw. Het was in die tijd heel gebruikelijk het beeld zo te herstellen dat de beschadigingen geheel weggewerkt werden, om een zo hoog mogelijke prijs te kunnen vragen. Aan de 'zwakke' bibberende lijnen is hier duidelijk te zien dat dit niet door een Chinese hand is ingeschilderd. Iedere Chinees leerde immers van jongs af aan met een penseelameteaccess 

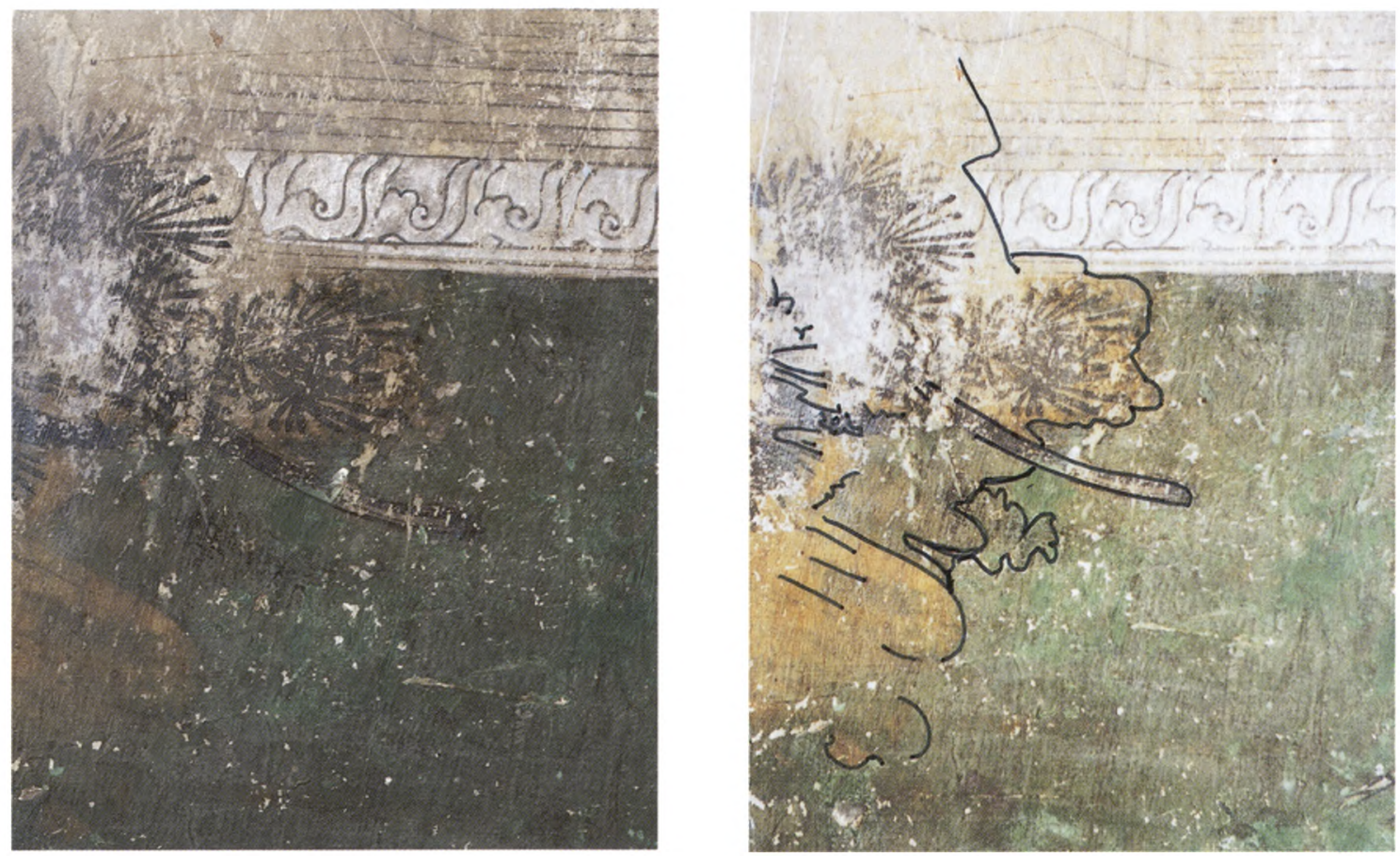

Afbeelding 5 en $5 a$ Het zwaard dat deze figuur in de hand houdt is nog zichtbaar onder de overschildering. gaan om karakters te schrijven en moest daarbij sterke scherpe lijnen gebruiken voor de kalligrafie. Daarom lijkt het waarschijnlijk dat deze bibberlijnen door een westerse hand aangebracht zijn om de voorstelling weer compleet te maken.

Een beschadiging links aan de rand van de voorstelling lijkt duidelijk wel ingevuld met een Chinese hand van schilderen. Op die plaats heeft oorspronkelijk een figuur gestaan die werd beschadigd en verloren ging bij het van de muur nemen van dit fragment.

Onder UV-licht is goed te zien dat er enkele reparaties aangebracht zijn in de onderlaag aan de gedecoreerde rand van de lambrizering; deze reparaties zijn ook overschilderd. ${ }^{4}$ In het Maandblad voor Beeldende Kunst staat een afbeelding die voor deze restauratie gemaakt is. ${ }^{5}$ Een beschadiging aan de onderrand laat een stuk van de ondergrond zien. Hier zag ik met een loep onder andere witte kiezel, kleine zwarte brokjes, enkele lange vezels met kleine stekeltjes en enkele rafelige afgeplatte geelbruine steeltjes. Op enkele plaatsen is de groene laag zelfs zo dun dat er vezels in de ondergrond zichtbaar zijn.

\section{Monsters van de verflagen}

In overleg heeft Rijksmuseummedewerker Arie Wallert een aantal monsters genomen van de verflaag van de schildering op de plaatsen die daarvoor het meest geschikt waren en het minst beschadiging zouden achterlaten. Voor het nemen van de monsters hebben we geprobeerd plaatsen te kiezen waar de originele verf nog aanwezig is en waar zo min mogelijk gerestaureerd is. Daarvoor gebruikt men een hele kleine naald en een fijn penseeltje voor het manipuleren van de minuscule fragmentjes. Deze speldenprikjes moeten straks meer informatie geven over de samenstelling van de verf. via free access 
De volgende monsters zijn genomen:

$74 / 1$ groene vloer (dit monster is helaas verloren gegaan tijdens het inbedden)

$74 / 2$ is afkomstig van de gele voorkant van de mantel van figuur $1^{6}$

$74 / 3$ van de witte linker schoenzool van figuur 1

$74 / 4$ van het rode deel van de mantel van figuur 1

$74 / 5$ van de vergulde opgehoogde lijn langs de gordel van figuur 2

$74 / 6$ van het groen van mantel van figuur 2 (dit monster is te klein om in te bedden)

$74 / 7$ van de zwarte rand langs de mantel van figuur 3

$74 / 8$ van de witte lambrizering van de muur achter de figuren

De monsters werden in een transparante polyester ingebed en na een verdere bewerking van schuren en polijsten waren ze klaar en kon met een microscoop de dwarsdoorsnede van de verflaag worden bekeken. Uiteindelijk werden zes monsters op een later tijdstip met SEM (scanning electron microscope) bekeken. Het monster 74/5 werd bovendien met EDX (energie dispersieve röntgenanalyse) geanalyseerd.

\section{Vergulding met melkgoud}

Op enkele plaatsen, bijvoorbeeld in de ceintuur van de mantels van figuur 1 en 2, liggen vergulde lijnen opgehoogd op de schildering. De vraag rees of hiervoor echt goud gebruikt is en met welke techniek dat is aangebracht. Het monster leverde in dit geval een mooie dwarsdoorsnede op.

Op afbeelding 7 is duidelijk te zien dat er voor de ophoging een vrij compacte witte massa met een fijne structuur gebruikt is: daarboven bevindt zich een laagje fijne deeltjes van ongeveer $10 \mu \mathrm{m}$ dik. ${ }^{7} \mathrm{Na}$ analyse blijkt het inderdaad goud te zijn. Dit goud is aangebracht in de vorm van rujin 'melkgoud'. Rujin is een typisch Chinese methode die afwijkt van de methode met bladgoud die wereldwijd het meest bekend is. Yu Fei'an vermeldt in zijn boek uit 1957 Zhongguo huihua yanse de yanjiu, [Het onderzoek van Chinese kleurstoffen], dat rujin door de schilders zelf gemaakt wordt. Hiervoor nemen ze bladgoud tussen wijsvinger en duim en wrijven dit samen met lijm net zolang tot het een verwerkbare verf geworden is (afb. 7).

In een Chinees schildershandboek staat in een recept beschreven hoe het materiaal vroeger voor het ophogen tot een verwerkbare pasta gemaakt werd: 'Het belangrijkste traditionele materiaal is samengesteld uit talkpoeder, beenderlijm en een vaste hoeveelheid tongolie ter voorkoming van barsten. Tegenwoordig is rujiao (melklijm) de meest gebruikte methode; dit is een emulsie met talkpoeder maar zonder tongolie. Hierdoor zijn er geen problemen met de temperatuur van de lijm. Als de lijnen breed zijn moet de emulsie dik zijn en voor fijne belijningen moet hij dunner zijn. De mix moet precies blijven staan en niet wegvloeien.' 8

In China zijn door de eeuwen heen verschillende soorten muren gebruikt om op te schilderen. Ik wil enkele van de meest gebruikte soorten noemen: als eerste is er de (nog steeds in gebruik zijnde) methode met in de zon gedroogde stenen van leem. Deze kunnen gebruikt worden in muren, zonder dat daar een bakproces aan te pas komt. De muur wordt van een gladde sliblaag en van een witte grondlaag voorzien, waarop dan de schildering kan wordene access 


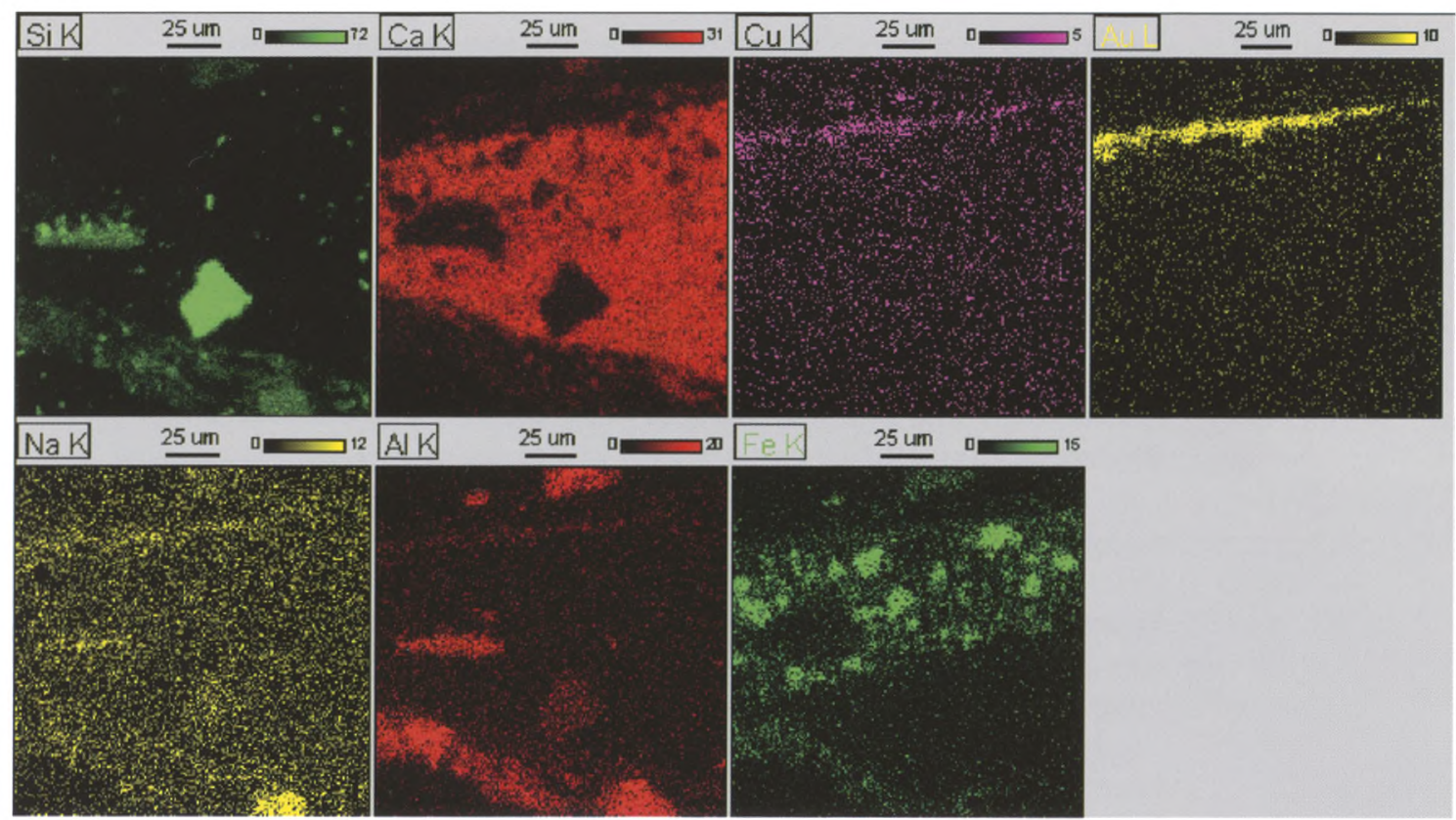

\section{Afbeelding 6 (boven)}

Monster 74/5; goudlaag

\section{SEM-foto.}

\section{Afbeelding 7}

Microscoopopname

van de dwarsdoorsnede monster 74/5. Hier is goed te zien hoe het goud in een dunne laag van kleine deeltjes op de witte grondlaag is aangebracht.

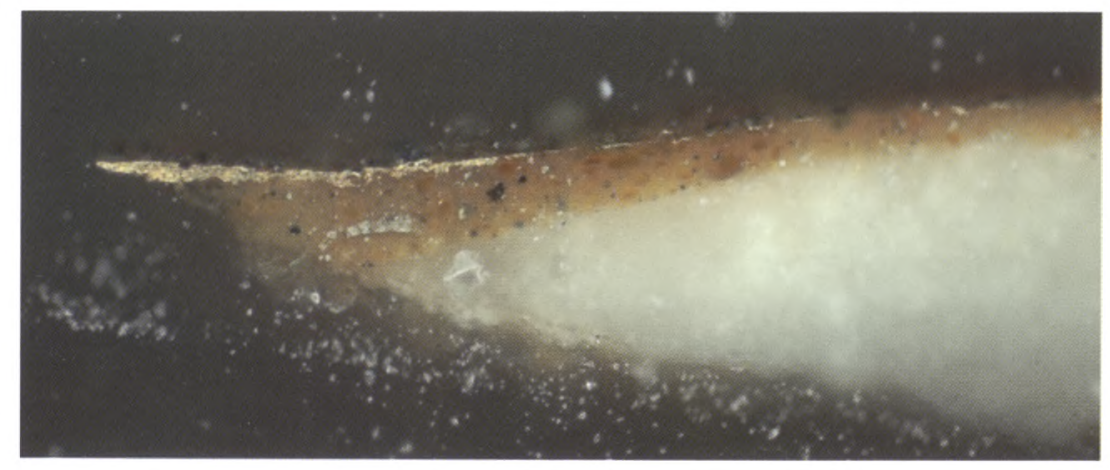

Afbeelding 8 (onder) Monster 74/5; de witte laag geeft de vergulding weer

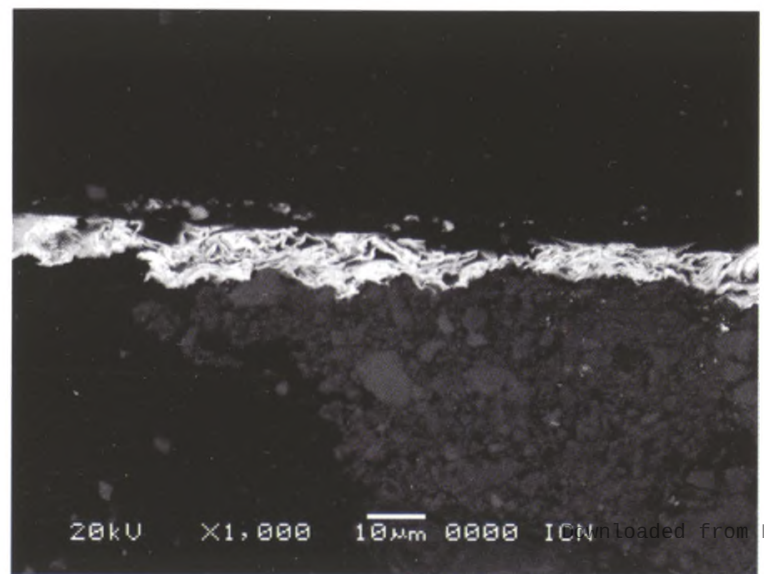


aangebracht. Ten tweede waren er vroeg in de geschiedenis wanden van grotten die na het prepareren gebruikt werden om op te schilderen. Hier zijn de wereldberoemde Mogao grotten in Dunhuang een mooi voorbeeld van. In ons geval hebben we, gezien de dikte van de leemlaag, waarschijnlijk te maken met de derde vorm: een dikke laag leem gemengd met stro wordt tussen de constructie van staande houten balken aangebracht. Op deze leemlaag worden dan een tussenlaag van fijner leem en uiteindelijk een witte preparatielaag aangebracht. De eerste tussenlaag van fijn leem wordt meestal gemengd met vezels van hennep of soms met papierafval. In een specifieke korte periode gedurende de Tang-dynastie (668-906) werd er lokale boomkatoen gebruikt ter versterking van deze tussenlaag. ${ }^{9}$ Dit is een van de vondsten in mijn eerdere onderzoek naar de muurschilderingen uit de $8^{\mathrm{e}}$ eeuw. ${ }^{10}$ De tweede tussenlaag is meestal wit en kan uit verschillende materialen bestaan zoals krijt, kalk of kaolien, dat ook wel Chinese porseleinaarde of Chinese klei genoemd wordt.

\section{Resultaten van de SEM-testen}

Hoewel dit niet de plaats is voor een technische verhandeling wil ik toch, voor de meer in techniek geïnteresseerde lezer, een korte beschrijving toevoegen van een deel van testresultaten van de onderzochte monsters.

Lood is opvallend aanwezig omdat het in twee verschillende vormen voorkomt: loodwit en loodgeel. Het in China veel voorkomende minium (roodlood) hebben we niet gevonden. De onderlaag van de monsters is overal hetzelfde. De tussenlaag is niet overal van de zelfde samenstelling, hetgeen wijst op het bewuste gebruik van een specifieke onderlaag voor specifieke kleurstoffen.

In het monster 74/2, dat afkomstig is uit de gele mantel van figuur 1 , bestaat de onderlaag uit calciumcarbonaat met sporen van magnesium en silicium. Dit wijst op het gebruik van een talkhoudend mineraal in de grondlaag voor de ophoging onder de vergulding, precies zoals het in het hierboven reeds beschreven traditionele recept wordt aangeraden. In China komen veel verschillende vormen van talkhoudende mineralen voor. Door de uiterst geringe hoeveelheid materiaal in het monster hebben we niet kunnen testen of ook de in het recept genoemde tongolie aanwezig is.

De bovenste verflaag van dit monster bevat lood, koper en sporen van fosfor. Deze combinatie levert een zachtgele kleur op, die overigens waarschijnlijk onder invloed van tijd enigszins vervaagd kan zijn. Deze loodhoudende gele verf is bekend als loodmonoxide, litharge of massicot.

In de toplaag van monster 74/3 zien we een witte verflaag. ${ }^{1}$ Dit is een mooi voorbeeld van loodwit, dat in China door de eeuwen heen gebruikt werd als witte kleurstof. De grondlaag bevat naast calcium, aluminium en magnesium, ook nog ijzer en bariumsulfaat en sporen van arsenicum. Dit wijst op de aanwezigheid van kaolien.

In monster 74/4, afkomstig van de achterkant van de mantel van figuur 1 , zien we tussen de leemgrondlaag en de verflaag een fondantachtige laag die hoofdzakelijk blijkt te bestaan uit veel voorkomende veldspaat. De aanwezigheid van kleine sporen fosfor en zwavel geven de indicatie dat er in deze laag ook beender-as aanwezig is. ${ }^{12}$ In dit monster is onder de microscoop te zien dat de leemgrondlaag fijne vezels bevat, vermoedelijk hennepkaf, maar nadere identificatie is niet mogelijk aan de hand van deze zeer kleine monsters. De witte tussenlaag 
bestaat werderom uit calciumcarbonaat met sporen van magnesium. De zeer dunne rode toplaag is een ijzerhoudende verf, waarschijnlijk een rode aarde ofwel hematiet. Dit is een in China veel gebruikte rode kleurstof.

De toplaag van monster 74/5 bestaat uit zuiver goud dat in kleine deeltjes op de opgehoogde onderlaag ligt. Het goud vinden we uitsluitend in de toplaag. De onderlaag bevat verspreide koperdeeltjes met een concentratie van koper vlak onder de toplaag. In de onderlaag vinden we verder hier en daar enkele korrels silicium en sporen van natrium en calcium die gelijkmatig verspreid voorkomen. Op enkele plekken in de grondlaag vinden we wat aluminium en ijzer.

De samenstelling van de grondlaag en de tussenlaag van dit fragment is zonder twijfel typerend voor de Chinese herkomst. Dit geldt ook voor de gebruikte kleurstoffen. Daarbij vormt het gebruikte rujin, melkgoud een sterk bewijs. Het is aan de hand van de gegevens waar we nu over beschikken niet mogelijk de plaats van herkomst vast te stellen. Ook de periode waarin het gemaakt is kan niet vastgesteld worden. De samenstelling van de grondlaag en de specifieke kenmerken van de loodhoudende monsters kunnen mogelijk op termijn wel gebruikt worden voor een nadere plaatsbepaling. In China is op dit moment nog geen referentiecollectie beschikbaar, maar in de komende jaren zal ik deze testresultaten blijven vergelijken met nieuwe publicaties van in-situ onderzoek van Chinese muurschilderingen.

\section{Noten}

1. $3^{\mathrm{e}}$ serie nummer $17 / 18,1968$.

2. zie afbeelding 1

3. lössgrond

4. plaatsaanduiding ten opzichte van de randen: $16 f l 23.5 f$ en in de mantel van een van de figuren 30 fl 30 i.

5. Maandblad voor Beeldende Kunst 13 (1936), p. 244.

6. De figuren zijn genummerd van links naar rechts.

7. $10 \mu \mathrm{m}$ is $0,001 \mathrm{~mm}$ dus dit laagje is slechts eenduizendste $\mathrm{mm}$.

8. Bihua chuangzuo, [De productie van muurschilderingen], Beijing gongyi meishu chubanshe, Beijing, 1993.

9. mumian, Chinese boomkatoen, komt van de Ciba pentadra.

10. Lucien van Valen, The Matter of Chinese Painting, Case studies of $8^{\text {th }}$ century Murals, z.pl., 2005.

11. Het monster $74 / 8$ afkomstig van de witte lambrizering op de achtergrond bevat ook loodwit.

12. Beender-as wordt gemaakt door het verbranden (calcineren) van dierlijke botten. 


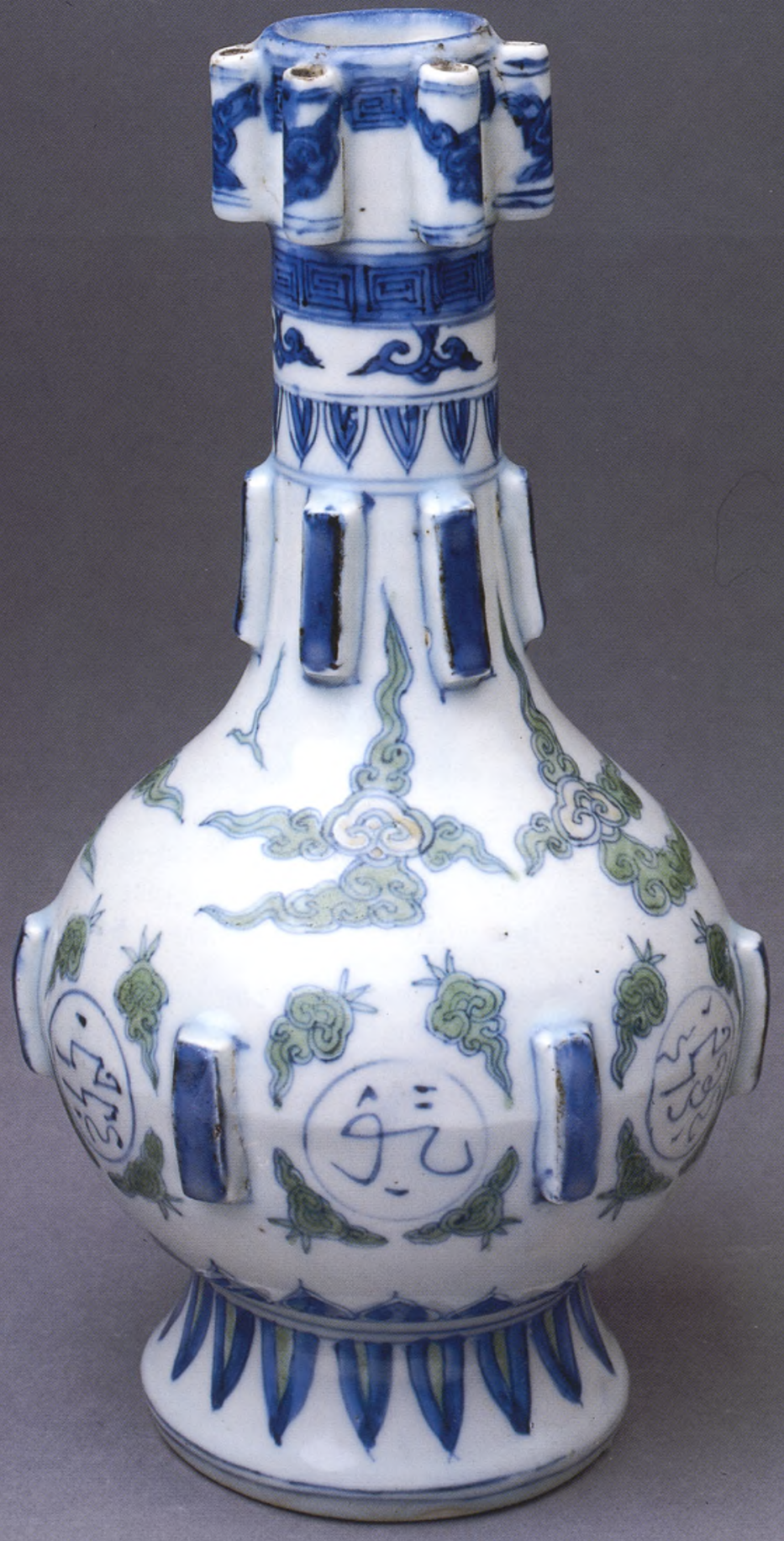

